\title{
The Effect of Decentralization Policy in Improving Community Welfare Regional Government of Special Yogyakarta - Indonesia
}

\author{
Budi Supriyatno ${ }^{1,2}$ \\ ${ }^{1}$ Universitya Satyagama Jakarta, Indonesia \\ ${ }^{2}$ Satyagama College of Computer Science Management (SMIK), Jakarta, Indonesia \\ Correspondence: Budi Supriyatno, Universitya Satyagama Jakarta, Indonesia \& Satyagama College of Computer \\ Science Management (SMIK), Jakarta, Indonesia.
}

Received: November 11, 2020

Accepted: December 23, 2020

Online Published: January 6, 2021

doi:10.5539/mas.v15n1p95

URL: https://doi.org/10.5539/mas.v15n1p95

\begin{abstract}
The Special Region of Yogyakarta is a Special Region at the provincial level in Indonesia which is the fusion of the Sultanate of Yogyakarta and the Paku Alaman Duchy. The Special Region of Yogyakarta is located in the southern part of the Indonesian Island of Java, and is bordered by the Provinces of Central Java and the Indian Ocean. Specialties of the Special Region of Yogyakarta must also play a role as an autonomous region implementing decentralization. However, the problem is that the policies, implementers and implications of decentralization have not been able to improve the welfare of the people. This can be seen from the level of income gap in the Special Region of Yogyakarta getting higher. Even the gap in the Special Region of Yogyakarta is above the national figure. The Government of the Special Region of Yogyakarta is expected to be able to encourage and run activities programs that are focused on people's welfare. Development must be directed to create jobs and increase community income so that people's welfare increases. This study aims to measure the effect of decentralization policies on improving the welfare of the people in the Yogyakarta Special Region Government.
\end{abstract}

Keywords: decentralization, policy, community, welfare, regional government

\section{Introduction}

Special Region of Yogyakarta (DIY) is a Special Region at the provincial level in Indonesia which is the fusion of the Sultanate of Yogyakarta and the Paku Alaman Duchy. The Special Region of Yogyakarta is located in the southern part of the Indonesian Island of Java, and is bordered by the Provinces of Central Java and the Indian Ocean. The Special Region which has an area of $3185.80 \mathrm{~km}^{2}$ consists of one city and four districts. According to the 2010 population census it has a population of $3,452,390$ people with a proportion of $1,705,404$ men, and 1,746,986 women, and has a population density of 1,084 people per $\mathrm{km}^{2}$. (Note 1 )

In the procedure for filling the position of governor, and vice governor one of the conditions that must be fulfilled by candidates for governor, and deputy governor is enthroned as Sultan Hamengku Buwono for the candidate for Governor, and enthroned as Duke of Paku Alam for the candidate for Deputy Governor. (Note 2)

The special features of Yogyakarta Special Region are inseparable as well as the role of an autonomous region implementing decentralization based on Republic of Indonesia Law No. 23 of 2014 concerning Regional Governmen. (Note 3)

However, the problem is that the policies, implementers and implications of decentralization have not been able to improve the welfare of the people. This can be seen from the level of income gap in the Special Region of Yogyakarta getting higher. Even the gap in the Special Region of Yogyakarta is above the national figure. Based on data from the Central Statistics Agency, the Gini ratio for the Yogyakarta Special Region reached 0.440, while the national ratio was 0.391 . The level of the Gini ratio in the Special Region of Yogyakarta increased from 0.432 in the March 2017 period to 0.440 in September 2017 (Note 4).

The Government of the Special Region of Yogyakarta is expected to be able to encourage and run activities programs that are focused on people's welfare. Development must be directed to create jobs and increase community income so that people's welfare increases. 


\section{Formulation of the Problem}

Referring to the above problems, the researcher formulated the main problem in this study, namely: Does the implementation policy, the implications of decentralization significantly affect the improvement of people's welfare in the Special Region of Yogyakarta?

\section{Research Purposes}

This study aims to measure how the influence of decentralization policies on improving the welfare of the community in the region, especially the Yogyakarta Special Government.

\section{Literature Review}

\section{Decentralization}

According to Budi Supriyatno, decentralization is defined as the granting of authority and responsibility for handling public functions from the central government to regional governments. This is because in the centralized system, the government enforces uniformity of treatment in each region (Note 5). Oates, (1972) stated that this "one size fits all" policy caused the uniqueness of each region to be accommodated, so that this policy model was seen as not reflecting local needs (Note 6).

According to Cheema and Rondinelli (1983) provides a broader definition of: "The transfer of responsibility for planning, management, and resource-raising and allocation from the central government to (a) field units of central government ministries or agencies; (b) subordinate units or levels of government; (c) semiautonomous public authorities or corporations; (d) area-wide regional or functional authorities; or (e) NGOs / PVOs" (Note 7).

In the context of the unitary state, the policy of granting autonomy to the regions is a typical policy that happens as much as in Indonesia. Here the granting of authority is based on several justifications:

First, in a unitary state, the granting of autonomy is actually a manifestation of people's sovereignty as a unity of the nation, not as the sovereignty of various independent national community groups.

Second, the fact that the central government will not be able to adequately regulate and manage the interests of a society that is very diverse and in a very far geographical range.

Based on these, then, the central government decentralizes its authority to the regions so that the regions can meet the interests and aspirations of the local people more effectively and efficiently.

In addition to these reasons, Bird and Vaillancourt (1998) state that decentralization policy has become a popular policy lately because this policy model promises to occur: economic efficiency, program cost effectiveness, accountability, increased resource mobilization, reduced disparity (disparity), increased political participation, and strengthening democracy and political stability (Note 8). Through decentralization, local governments play a greater role in development because they now have the authority and responsibility to carry out community development in their areas.

\section{Community Welfare}

The term community welfare itself should not be defined in a narrow sense, which only uses the amount of Gros Regional Domistic Product (GRDP) per capita as an approach but must involve several other indicators that are considered to be supporting elements of the concept of public welfare in a broad sense. In the Republic of Indonesia Law No. 6 of 1974 concerning Basic Provisions for Social Welfare, in the general explanation section stated that "the field of social welfare is very broad and complex, which includes among others, aspects of education, health, religion, labor, social welfare and others".

Judging from the definition, it can be concluded that the assessment of welfare has 2 (two) dimensions, namely the physical and psychological dimensions. Given the psychological dimension, its nature is very subjective and the measurement process is not easy, so most studies more often use physical dimensions as a measure of people's welfare. Therefore, there are currently many developing welfare measurements from the point of view of physical dimensions, for example the Human Development Index, the Physical Quality Life Index; Basic Needs, etc.

Theoretically, the level of community welfare in the regions should be better when the decentralization policy is implemented considering the quality of information and the level of transparency in the administration of governance in the era of decentralization is better than from the era of centralization. However, although decentralization seems to have been a "profitable" style of government management over the last few decades, Bardhan and Mookherjee (2005) mention that the effects of decentralization differ from country to country 
(Note 9). This means that decentralization policies cannot guarantee they will always bring depends on local conditions. In other words, decentralization is not always effective in improving people's welfare. Elhiraika (2007) states that the reason behind this phenomenon is because of the "lack of commensurate revenue assignments, inadequate access to financial markets, and lack of necessary administrative capacity" (Note 10).

During this time, quantitative studies on decentralization have used more fiscal or financial approaches as approaches. But Bird, in Hong (2011), given the degree of autonomy of a positive influence due to different local governments, the effect would be highly inappropriate if measuring decentralization was only seen from the fiscal aspect (Note 11). Zimmerman states that decentralization should be measured not from a single index only, but by multiple interrelated indicators, which include 4 (four) dimensions, namely: dimensions of structure, finance, functions, and personnel (Note 12). Stephens (in Hong, 2011) also proposed three dimensions namely financial, functional, and personnel dimensions to measure the degree of decentralization of local government (state government) in the United States (Note 13).

\section{Research Method and Analysis}

\subsection{Research Objects}

In this study, the object of research as well as population is the Government of the Special Region of Yogyakarta consisting of Bantul Regency, Gunung Kidul, Kulon Progo, Sleman and Yogyakarta City. This study as a whole will use data from the Government of the Special Region of Yogyakarta since 2014-2019.

\subsection{Research Variables}

\section{Decentralized Variable}

By calculating the possibility of a measurement, the decentralization variable in this study is measured in 3 (three) dimensions:

a. The degree of Fiscal Decentralization is measured using the percentage of the Original Local Revenue approach to total regional revenue.

b. The degree of Functional Decentralization is measured by the percentage of regional government expenditure out of the total national government expenditure. As explained by Hong (2011), in fact the most accurate approach to measure the degree of functional decentralization is the percentage of functions carried out by local governments to total government functions, however, time-series data from these approaches are difficult to collect, so this research is used expenditure approach (Note 14).

c. The degree of Decentralization of Personnel is measured by the percentage of regional Civil Servants towards the central Civil Servants.

\section{Variable Control}

Control variables consisting of Investment and Labor Variables. This control variable is made in order to see the possibility of other variables outside the studied variables, which are considered to affect the level of community welfare in an area. The variable referred to labor will use the percentage of labor force approaches that have worked. The investment variable used in this study is the ratio of total Domestic Investment and Foreign Investment to GRDP in a Regency / City in the Special Region of Yogyakarta. The selection of investment variables and labor variables as control variables is due to this variable allegedly having an influence on the economic growth of a region as used in the study of Jing Jin and Heng-fu Zou (2000) (Note 15).

\section{Dependent Variable}

\section{a. Variable Gross Regional Domestic Product per capita}

Dependent variables in this study are variables related to community welfare that are defined in a broad sense, which includes several aspects such as: regional economic aspects, infrastructure aspects, educational aspects and health aspects. Variables that become approaches from regional economic aspects include: Gross Regional Domestic Product variables per capita. This is based on the logic that the Gross Regional Domestic Product per capita variable provides information about how much value added is generated in each region, so it is a basic indicator for understanding the economic condition of an area as a whole.

\section{b. Variable Length of Road Increase Per Capita}

The variable used in this study is the variable length of road per capita. This variable is considered important in supporting the creation of regional welfare. Judging from the theory, the length and condition of the roads are closely related to the comfort of life of each citizen which can be further linked to aspects of community welfare. 


\section{c. Education Indicator}

To measure education indicators, this study uses the approach of the number of school buildings per population and the ratio of students to teachers for the education level of senior high school. The first variable shows the level of accessibility of the community to secondary education infrastructure, while the second variable shows the quality of education level in terms of the composition of the teacher to student ratio.

\section{d. Health Indicator}

To measure health indicators, this study uses the approach of the number of doctors per 1,000 population and the number of beds in hospitals per 1,000,000 residents. Here, the number of doctors is an indicator that is widely used to represent the development of health services. Meanwhile, the number of beds in the hospital, although it does not appear to be directly related to regional development, can certainly be closely related to the level of welfare of an area.

Similar to the treatment of independent variables, this research is also not based on the idea that if regional differences are not measured by a single indicator but rather measured by various indicators that represent various aspects, then this is considered more persuasive to see various aspects of community welfare in the Special Region of Yogyakarta compared if it must be arranged in one composite index.

\subsection{Analysis Method}

\section{Quantitative descriptive}

The analytical method used in this research is quantitative descriptive. This analysis method aims to provide an overview, study and test the existence of the theory empirically of the independent variables that affect a dependent variable. Descriptive analysis methods are prepared based on secondary data, literature, journals, papers, articles and previous research results relating to the problem under study. In conducting quantitative analysis methods carried out through econometric modeling which is interpreted statistically. The data processing technique is done by using the Reviews Program.

\section{Data Types, Data Collection Techniques and Data Sources}

The data used in this study is panel data to produce an index that is composite data composite to measure the level of community welfare. It consists of time series data and cross section data from 5 districts / cities in Yogyakarta Special Region. Data collection techniques are carried out through library research activities from various sources to find a factual description, starting with literature review and reviewing related research results, so that a clear and comprehensive picture of the object and analysis will be obtained.

\section{Research Model}

The model used in this study refers to the model developed by Hong (2011) with some adjustments in defining the independent variables that are used to measure the degree of decentralization and also the dependent variable that explains about people's welfare.

Furthermore, mathematically the models used in this study were 6 (six) models, which were formulated as follows:

1) To see the effect of decentralization policy on community welfare in the economy in the Special Region of Yogyakarta, use Model 1:

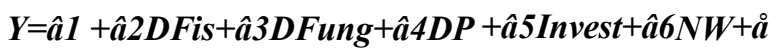

2) To see the effect of decentralization policies on community welfare in infrastructure, Model 2 is used:

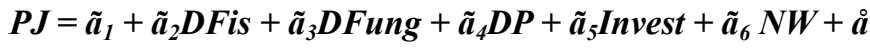

3) To see the effect of decentralization policy on the welfare of the community in the field of education, Model 3 and Model 4 are used as follows:

$R H S B=\grave{e}_{1}+\grave{e}_{2} D F i s+\grave{e}_{3} D F u n g+\grave{e}_{4} D P+\grave{e}_{5}$ Invest $+\grave{e}_{6} T K+\grave{a}$

$S T=\ddot{a}_{1}+\ddot{a}_{2} D F i s+\ddot{a}_{3} D F u n g+\ddot{a}_{4} D P+\ddot{a}_{5}$ Invest $+\ddot{a}_{6} T K+\ddot{a}$

4) To see the effect of decentralization policy on community welfare in the field of health, Model 5 and 
Model 6 are used as follows:

$D R C a p=\tilde{n} 1+\tilde{n} 2 D F i s+\tilde{n} 3 D F u n g+\tilde{n} 4 D P+\tilde{n} 5 I n v e s t+\tilde{n} 6 T K+\stackrel{a}{0}$

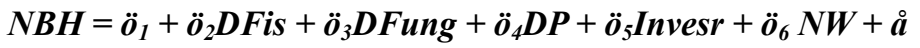

Where:

Ypcap Y = GRDP (Gross Regional Domestic Product) per capita;

LRcap $=$ Length of Road of good quality per capita;

DRcap $=$ ratio of doctors per 1000 population;

RHSB = Ratio of High School Buildings per population;

$\mathrm{ST}=$ High School Student and Teacher ratio;

$\mathrm{NBH}=$ Ratio of Number of Beds in Hospital per 1,000,000 population;

Dfis $=$ Fiscal Decentralization;

Dfung $=$ Functional Decentralization;

$\mathrm{DP}=$ Decentralized Personnel;

NW $=$ Number of Workers;

Invest $=$ Investment;

â, ã, ä, è, $\tilde{n}=$ Regression Coefficient;

$\AA$ = Error Term (interference).

\section{Estimation Techniques, Model Evaluations and Statistical Test Criteria}

Estimation Techniques, Model Evaluations and Statistical Criteria Tests In this study three estimation techniques will be used namely: the PLS (Panel Least Square) method or known as the Common Effect model, Fixed Effect model, and Random Effect model. After that, the suitability of the model will be tested using the test: Chow Test, Hausman Test and Langrange Multiplier (LM) test. Meanwhile, the statistical criterion tests carried out include the estimation of the coefficient of determination (R), the partial significance test with the $t$ test and the overall regression coefficient test with the $\mathrm{F}$ test.

\section{INDICATORS}

\section{1) Decentralization Indicators}

In various related studies, to measure fiscal decentralization in an area, the variable that is often used is expenditure and revenue. Ebel and Yilmaz (2002) state that there are variations in the selection of indicators to measure the degree of decentralization between one country and another (Note 16). That is, although both use government expenditure and revenue variables, the size variables used can vary.

Previous studies have used variable variables of the degree of fiscal decentralization that are highly variable. In terms of revenue, a number of approaches are used, for example the Regional Budget Revenue share variable (Elhiraika, 2007) (Note 17); percentage of local tax revenue divided by total national tax revenue (Hong, 2011) (Note 18); PAD share of total regional revenue, share revenue sharing of total regional revenue, and share of balancing fund of total regional revenue (Altito, 2010;Tasrin, 2011; Jin Jin and Heng-fu, Zou, 2000) (Note 19).

Meanwhile, several variables in terms of expenditure are used to measure the degree of fiscal decentralization in several previous studies, including: the ratio of local government expenditure to total national expenditure (Jin Jin \& Heng-fu, Zou, 2000; Slinko, 2002) (Note 20).

In fact, the use of revenue and expenditure indicators as an approach to measure the degree of fiscal decentralization contains weaknesses. The explanation of this is as follows: The problem with the expenditure decentralization is that local government usually does not have a real degree of autonomy but act on behalf of the regional and federal government We also have problems with the revenue side source revenue) to the total estimation of fiscal regional income and the share of the transfer of funds to total revenue 240 decentralization since those also could not be the consequence of municipal ability to rise and assign taxes, but the consequences of revenue-sharing policies of regional government (Note 21). 
However, in this study, the revenue approach will still be used as an approach variable to measure the degree of fiscal decentralization. The variables to be used are the share of Original Regional Revenue to total regional revenue, as used in the research of Jin and Heng-fu, Zou (2000), Slinko (2002), Elhiraika (2007) (Note 22). The use of this variable is based on justification that the Regional Original Revenue is a measure of regional independence. It actually states that Local Revenue reflects "sufficient" local taxing power as a necessary condition for the realization of broad regional autonomy. This is because local tax and local user fees are the main sources of Regional Original Revenue.

This study will also use variables from the aspect of expenditure (expenditure), namely the ratio of regional expenditure to national expenditure. This variable was also used by Hong (2011) in his research which took the South Korean case study (Note 23), only Hong placed this variable not as part of the fiscal decentralization variable but rather the use of the fiscal decentralization variable as the only variable used to measure the degree of decentralization, more or less has been answered by Hong (2011) through the use of several other variables outside the fiscal decentralization variable (Note 24).

This refers to Zimmerman's statement which argues that the definition of decentralization must be measured not by a single index, but by several interrelated indices (Note 25). Here Zemmerman in Hong (2011) classify decentralization into four dimensions of structure, function, finance, and personnel (Note 26). Referring to the concept of Zimmerman's decentralization, Hong (2011) research, negates structural aspects and uses three other dimensions namely: the dimensions of function, finance and personnel (Note 27). In a more comprehensive research framework, this study will adopt the approach carried out in Hong (2011) research (Note 28), which in addition to using the fiscal decentralization dimension also uses the functional decentralization and personnel decentralization dimensions.

\section{2) Community Welfare Indicator}

People's welfare is often approached by using the per capital Gross Domestic Product (GDP) approach. But in recent years, the use of GDP per capita as a unit of measurement that is often used to measure the welfare of society, has invited debate in various circles. This is because it often occurs out of sync between the numbers and the reality of "well-being" that occurs in society.

This problem subsequently led French President Nicholas Sarkozy, in February 2008, who was dissatisfied with the condition of statistical information on the economy and society at that time asking Joseph Stiglitz, AmartyaSen, and Jean-Paul Fitoussi to form the Commission on Economic Performance Measurement and Social Progress (CMEPSP) (Note 29). The making of this commission is intended to identify the limitations of Gross Domistic Products as indicators of economic performance and social progress.

Several previous studies have also tried to use a more comprehensive approach to explain the welfare of society. The latest trend interprets that the concept of community welfare in an area in a broad sense is interpreted as a condition where a good quality of life is achieved or the adequacy of basic human needs. Liu in Hong (2011) is an example of a case that uses a quality of life approach to measure the level of regional development (Note 30).

Here, Liu builds five dimensions of quality of life such as economic, political, environmental, health and education, and social, and then selects 123 indicators for the five dimensions (Note 31).

Furthermore, defining public welfare in this study will follow definitions according to Hong (2011) which not only uses the GRDP per capita indicator as the only indicator that explains public welfare, but also includes several dimensions related to basic public services such as education, health and infrastructure (Note 32 ). This is what makes the positioning of this research in the constellation of similar studies that have been carried out, as one of the studies using a fairly comprehensive approach.

\section{Discussion of Research Results}

\subsection{Estimated Results}

There are three techniques for estimating panel data regression models that can be used, namely models with the Common Effect Model or Pooled Least Square (PLS), Fixed Effect models and Random Effect models. In this study, all three estimation techniques are made to further be tested to determine which estimation techniques are most appropriate. Next, the following three estimation results are presented.

a. Estimation with the Pooled Least Square (PLS) or Common Effect Approach. The Pooled Least Square (PLS) approach does not pay attention to individual dimensions or time. Here the assumption is used that the behavior of the data between the units of analysis, in the form of regencies and cities of the Yogyakarta Special Region, has similarities in various periods of time. Furthermore, the PLS regression results are shown in Table 1.A. 
Table 1. Achievement of the Human Development Index (HDI), Results of Permanent Regression ResultsAnd Random Effect Regression Results of The Special Region of Yogyakarta

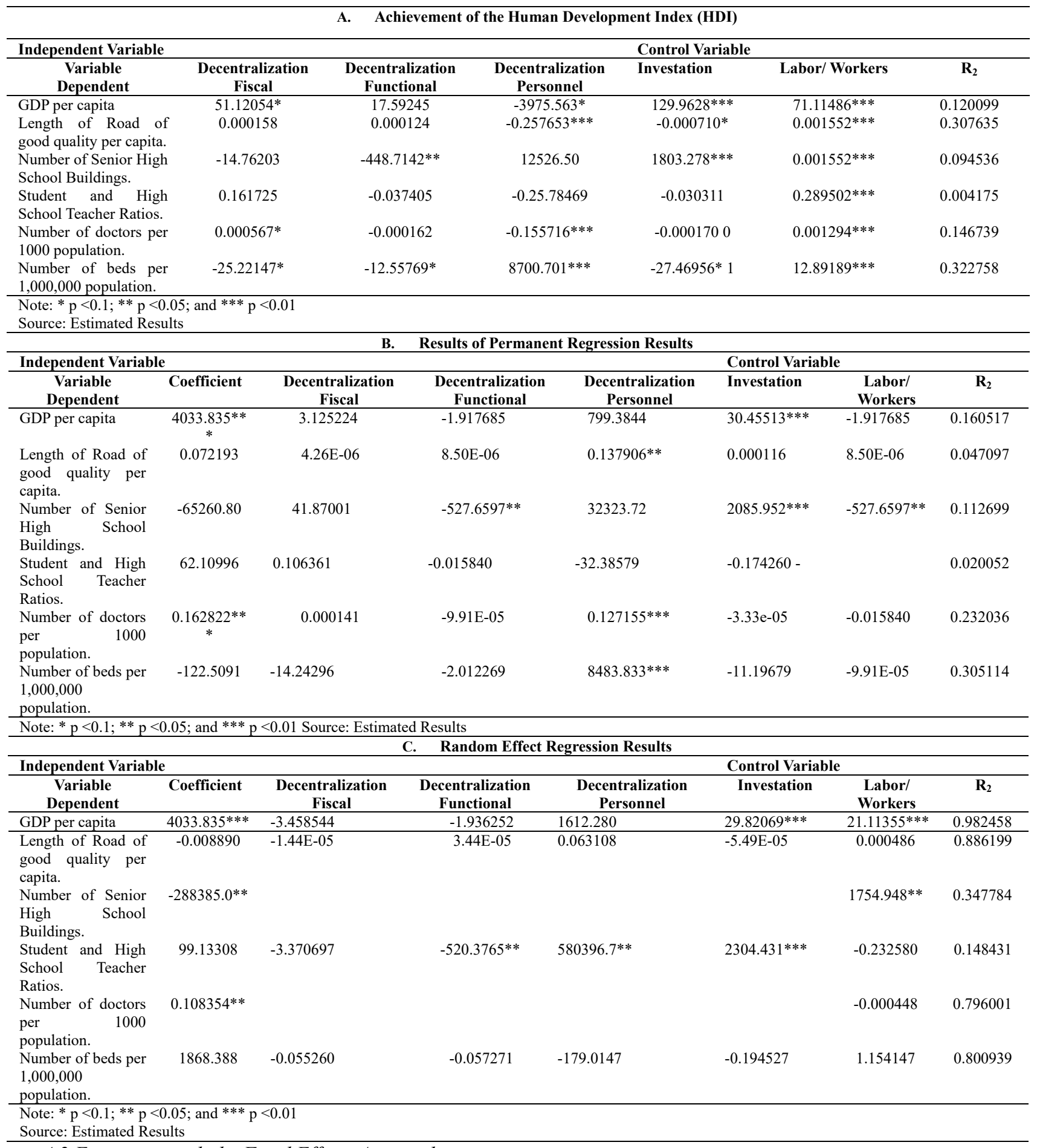

\subsection{Estimation with the Fixed Effects Approach}

These different characteristics must be accommodated in the model. One way is to change the assumption that intercepts differ between district/city analysis units in the Special Region of Yogyakarta while the slope between district/city analysis units remains the same. The model that assumes the existence of intercept differences in the equation is known as the Fixed Effects regression model. The results of the Fixed Effects regression are shown in Table 1.B. 


\subsection{Estimation with the Random Effect Approach}

In this approach, residual variables are used which assume that residuals may be interconnected between time and between individuals. The assumptions used intercept are random or stochastic variables. The right method used to estimate the Random Effect model is Generalized Least Squares (GLS). The results of the Random Effect regression are shown in Table 1.C.

After estimating with the three approaches above, it will then be determined which approach is the most appropriate to use. For this purpose this research will use 3 (three) types of tests, namely:

a. Chow Test, used to choose between OLS methods without dummy variables or Fixed Effect;

b. Hausman Test, used to choose between Fixed Effect or Random Effect; and

c. The Langrange Multiplier (LM) test is used to choose between PLS without dummy variables or Random Effects. The results of the three tests can be seen in the following

Table 2. Compilation of the Chow Test Results, Hausman Test and LM Test

\begin{tabular}{|c|c|c|c|c|}
\hline MODEL & & TEST RESULTS & & CONCLUSION \\
\hline \multirow[t]{2}{*}{ Model 1} & Chow Test & Hausman Test & LM Test & Random Effect \\
\hline & $\begin{array}{l}0.0000 \\
\text { (Fixed Effect) }\end{array}$ & (Random Effect) & $\begin{array}{l}0.0000 \\
\text { (Random Effect) }\end{array}$ & \\
\hline Model 2 & $\begin{array}{l}0.0000 \\
\text { (Fixed Effect) }\end{array}$ & $\begin{array}{l}0.0063 \\
\text { (Fixed Effect) }\end{array}$ & $\begin{array}{l}0.0000 \\
\text { (Random Effect) }\end{array}$ & Fixed Effect \\
\hline \multirow[t]{2}{*}{ Model 3} & 0.0050 & 0.1141 & 0.0008 & Random Effect \\
\hline & (Fixed Effect) & (Random Effect) & (Random Effect) & \\
\hline \multirow[t]{2}{*}{ Model 4} & 0.6703 & 0.5091 & 0.5098 & OLS/Common Effect \\
\hline & (OLS/Common Effect) & (Random Effect) & (OLS/Common Effect) & \\
\hline Model 5 & $\begin{array}{l}0.0000 \\
\text { (Fixed Effect) }\end{array}$ & $\begin{array}{l}0.1470 \\
\text { (Random Effect) }\end{array}$ & $\begin{array}{l}0.0000 \\
\text { (Random Effect) }\end{array}$ & Random Effect \\
\hline Model 6 & $\begin{array}{l}0.0000 \\
\text { (Fixed Effect) }\end{array}$ & $\begin{array}{l}0.0025 \\
\text { (Fixed Effect) }\end{array}$ & $\begin{array}{l}0.0000 \\
\text { (Random Effect) }\end{array}$ & Fixed Effect \\
\hline
\end{tabular}

\subsection{Analysis Results}

Based on the test results as shown in Table 2, then next to the ease of the analysis process will refer to Table 3 .

Table 3. Compilation Compatibility Of The Model Used

\begin{tabular}{|c|c|c|c|c|c|c|c|}
\hline \multicolumn{5}{|c|}{ Independent Variable } & \multicolumn{3}{|c|}{ Control Variable } \\
\hline $\begin{array}{c}\text { Variable } \\
\text { Dependent }\end{array}$ & Coefficient & $\begin{array}{c}\text { Decentralization } \\
\text { Fiscal }\end{array}$ & $\begin{array}{c}\text { Decentralization } \\
\text { Functional }\end{array}$ & $\begin{array}{c}\text { Decentralization } \\
\text { Personnel }\end{array}$ & Investation & $\begin{array}{c}\text { Labor/ } \\
\text { Workers }\end{array}$ & $\mathbf{R}_{\mathbf{2}}$ \\
\hline Model1 & $4033.835 * * *$ & -3.458544 & -1.936252 & 1612.280 & $29.82069^{* * *}$ & $21.11355^{* * *}$ & 0.982458 \\
\hline Model2 & $0.072193 * *$ & 4.26E-06 & $8.50 \mathrm{E}-06$ & $-0.137906 * *$ & -0.000116 & 0.000290 & 0.047097 \\
\hline Model3 & $-288385.0 * *$ & -3.370697 & $-520.3765^{* *}$ & $580396.7 * *$ & $2304.431 * * *$ & $1754.948^{* *}$ & 0.347784 \\
\hline Model4 & & 0.161725 & -0.037405 & -0.25 .78469 & -0.030311 & $0.289502 * * *$ & 0.004175 \\
\hline Model5 & $0.108354 * *$ & 0.000111 & $-8.55 \mathrm{E}-05$ & 0.003531 & $3.44 \mathrm{E}-05$ & -0.000448 & 0.796001 \\
\hline Model6 & -122.5091 & -14.24296 & -2.012269 & $8483.833 * * *$ & -11.19679 & 11.55429 & 0.305114 \\
\hline
\end{tabular}

Note: $* \mathrm{p}<0.1 ; * * \mathrm{p}<0.05$; and $* * * \mathrm{p}<0.01$ Models 1, 3, 5 using Random Effects, Models 2 and 6 using Fixed Effects, and Model 4 using OLS / Common Effects.

Source: Estimated Results.

\section{Model Analysis 1}

From Table 3, it can be seen that there is no direct effect between the degree of decentralization and the level of social welfare in the economy. This can be seen from the absence of a decentralized variable that significantly affects the economic variables of the Special Region of Yogyakarta, which is represented by the variable Gross 
Regional Domestic Product per capita. And when seen from the presence of control variables, it is clear that both investment variables and labor variables have statistically significant coefficients with the test at á $=1 \%$ and have a positive sign. This means that changes in the two control variables have a positive influence on the economy of the Special Region of Yogyakarta.

Although there is no direct influence between the three variables of decentralization and economic growth, there is an indication that the indirect effect of this variable is through investment channels, where high investment in the region is justified as a form of performance of local governments in attracting investment. Furthermore, the coefficient of determination (R2) of 0.98258 means that model 1 is able to explain variations in economic growth progress of $98.26 \%$, however, this effect does not originate from the decentralization variable.

\section{Model Analysis 2}

From Table 3 it can also be seen that only the personnel decentralization variable has a significant coefficient through the $\mathrm{t}$ test at $\mathrm{a}=5 \%$. This variable is negative, meaning that if there is an increase in the ratio of Civil Servants in the Special Region of Yogyakart to Central Civil Servants by one unit there will be a decrease in the ratio of good quality. This is most likely due to the large number of Civil Servants recruited by the Regional Government each year since the decentralization policy took effect. As a result, there is currently a swelling of the routine budget allocated for salaries and benefits of regional civil servants, while the road infrastructure development budget is constrained. On the other hand, the rate of population growth in the Special Region of Yogyakarta is relatively high, so with the lack of road construction carried out in the last 5 years, the ratio of the length of good quality roads per population is getting smaller. Furthermore, when viewed from a very small coefficient of determination (R2), which is equal to 0.047097 , it can be said that model 2 is only able to explain the variation in the growth of good quality road infrastructure by $5 \%$. This means that around $95 \%$ of the variation in the growth of good quality road infrastructure is influenced by other variables not included in this model.

\section{Model Analysis 3}

Table 3 also explains that there are two decentralization variables that have a significant influence on community accessibility in the upper secondary education sector represented by the variable number of senior high school buildings per population. The two decentralization variables referred to are functional decentralization variables, which are approximated by the variable ratio of local government expenditure to total government expenditure nationally, and the personnel decentralization variable represented by the variable ratio of regional Civil Servants to central Civil Servants. The significance level of these two variables is at the $95 \%$ confidence level or á $=5 \%$. However, these two variables have different effects. The functional decentralization variable is negative, meaning that an increase in the ratio of local government expenditure to total national government expenditure of 1 unit will affect the reduction in the ratio of the number of high school senior secondary schools per population.

The variable decentralization of personnel is positive, meaning that an increase in the ratio of the regional Civil Servants to the central Civil Servants by 1 unit will affect the increase in the ratio of the number of schools per population. This can be explained as follows: in the era of decentralization, many local governments undertook the recruitment of Civil Servants, including the recruitment of teaching staff or teachers at the High School Level. As a result of the large number of teaching staff / teachers, the government then built educational facilities in the form of school buildings, so the ratio of the number of schools per population increased.

Meanwhile, the two control variables, namely investment and labor variables, were each positive and statistically significant through the $t$ test at á $=1 \%$ and á $=5 \%$ respectively. This means that changes in these two variables have an influence on changes in the ratio of the number of schools per population. This is because the increase in investment also includes investment in the education sector, which consequently the demand for teaching staff / teachers for senior high schools also increases.

While the determination coefficient value of 0.347784 means the model is able to explain variations in the ratio of the amount per population of $34.78 \%$.

\section{Model Analysis 4}

The most suitable approach for model 4 is to use the PLS or Common Effect method. As seen in table 1.B, none of the decentralization variables has a significant effect on the ratio of students and teachers to senior secondary schools. It's just that the labor variable which is a control variable in this study, has a significance at á $=1 \%$. Similar to the explanation in model 1.C, the insignificance of the decentralization variable in this model is due to the fact that local governments are more focused on developing elementary school education and junior high 
school education which is part of the 9-year compulsory education program. Actually, the recruitment of teachers at senior high schools is still carried out, but there are not as many as at the elementary and senior high schools. Furthermore, when seen from the coefficient of determination (R2) which is very small, which is equal to 0.004175 , it can be said that model 4 is only able to explain variations in the ratio of students and teachers at the High School Level of $0.4 \%$. This means that around $99.6 \%$ of the variation in the ratio of pupils and teachers at the senior secondary level is influenced by other variables not included in this model.

\section{Model Analysis 5}

In model 5, it was found that the decentralization variable did not have a significant effect on changes in the ratio of the number of doctors per 1000 population. Furthermore, when viewed from the coefficient of determination (R2) which is 0.796001 , it can be said that although the variables in model 5 are not significant, but simultaneously, this model is able to explain variations in the ratio of doctors per 1000 population of $79.60 \%$. This means that only about $20.40 \%$ of the variation in the ratio of doctors per 1000 population is influenced by other variables not included in this model.

\section{Model Analysis 6}

For model 6, the personnel decentralization variable is positive and statistically significant through the $t$ test at á $=1 \%$. This means that if there is an increase in the ratio of the regional Civil Servants to the central Civil Servants by 1 unit it will affect the increase in the ratio of the number of beds in the Hospital per 1,000,000 population. Furthermore, when viewed from the coefficient of determination (R2) which is equal to 0.305114 , it can be said that model 6 is only able to explain the variation in the ratio of the number of beds in the Hospital per $1,000,000$ population by $30.51 \%$.

\section{Conclusions and Suggestions}

\subsection{Conclusions}

Based on the results of the analysis, the following conclusions can be made:

1) In the economic field, the decentralization variable has not shown any direct effect, either in terms of fiscal decentralization, functional decentralization and personnel decentralization. This can be seen from the absence of the coefficient of the decentralized variable which significantly influences the regional economic variable represented by the Gross Regional Per capita variable. The determinants that significantly affect economic growth in the area are explained by the presence of control variables, namely investment variables and labor variables where each variable has a statistical significance with a t test at á $=1 \%$ and has a positive sign. This means that under ceteris paribus conditions, an increase in the ratio of investment to Gross Regional Domistic Products and an increase in the ratio of labor to labor force of 1 unit, each will result in an increase in Gross Regional Dom per capita by the coefficient value as seen in model 1.

2) In the infrastructure sector, only the personnel decentralization variable has an influence on changes in the road infrastructure variable. However, the effect shown by the personnel decentralization variable is negative. This means that if there is an increase in the ratio of the regional Civil Servants to the central Civil Servants by one unit, there will be a decrease in the ratio of good quality road lengths by the coefficient value. Allegedly, this is caused by the different post as indicated by the coefficient of functional decentralization variable which is negative and the coefficient of decentralization variable in the implementation of personnel policy which is positive. A sign of decentralization, the regions began to recruit civil servants every year. As a result, the number of regional Civil Servants has increased and led to the swelling of routine budget requirements for the payment of salaries and benefits of regional Civil Servants. This in turn has implications for the decreasing budget for road infrastructure development.

3) In the field of Education, there are two decentralization variables that have a significant influence on community accessibility in the field of secondary education and above. The second variable decentralization that is agreed upon is the functional decentralization variable and the task decentralization variable. However, this second variable has a negative effect of this functional decentralization variable showing the ratio of increasing government to total government based on the number of units that will increase the ratio of the number of schools. Meanwhile, a positive sign of the decentralization variable regarding an increase in the ratio of the regional Civil Servants to the central Civil Servants by 1 unit will increase the ratio of the number of schools per population by its coefficient. In addition to model 3, model 4 also explains the effect of decentralization in the education sector as seen from the quality of top-level education represented by the dependent variable in the form of student and teacher ratios. In this model 4 , it was found that there was a decentralized variable that had a significant effect on the ratio of students to teachers at the Upper Level 
Education level. It's just that the labor variable which is a control variable in this study, has a significance at á $=1 \%$.

4) In the health sector, it was found that the decentralization variable did not have a significant effect on changes in the ratio of the number of doctors per 1000 population. However, for model 6 with the dependent variable in the form of the ratio of beds in the hospital to, it appears that the personnel decentralization variable is significant and positive. This means that if there is an increase in the ratio of the regional Civil Servants to the central Civil Servants by 1 unit it will affect the increase in the ratio of the number of beds in the Hospital per 1,000,000 population. Furthermore, related to the channel of the decentralization variable which is able to give effect to the improvement of people's welfare it can be concluded that the functional decentralization variable and the personnel decentralization variable are channels that contribute to the welfare of the community. However, the performance of these two channels must be improved in the future.

\subsection{Suggestions}

Based on the conclusions above, several suggestions were then formulated to direct the district / city governments in the Special Region of Yogyakarta to maximize their role in the framework of improving the functioning of the decentralization variable, both fiscal, functional and personnel decentralization variables. Some steps that can be done, namely:

1) Maximizing the role of fiscal decentralization by optimizing the performance of revenue instruments that are able to drive an increase in regional income, for example through optimizing regional taxes and charges which are one of the main components in Regional Original Revenue.

2) Optimizing the role of functional decentralization, through budget allocation policies that are adjusted to the regional vision and mission to improve public welfare and services.

3) Increasing the role of personnel decentralization through efforts to increase the capacity of Human Resources, namely Civil Servants.

\section{References}

Bird, R., \& Vaillancourt, F. (1998). Fiscal Decentralization in Developing Countries. Cambridge University Press, United Kingdom. https://doi.org/10.1017/CBO9780511559815

Central Bureau of Statistics of the Special Region of Yogyakarta Province. (2010).

Cheema, G. S., \& Rondinelli, D. A. (1983). Decentralization and Development: Policy Implementation in Developing Countries. Beverly Hills; London; New Delhi: Sage Publications.

Ebel, Robert D., \& Seidar, Yilmaz. (2002). Concept of Fiscal Desentralization and World Wide Overview. World Bank Institute. Retrieved from https://www.Worldbank.org

Elhiraika, A. B. (2007). Fiscal Decentralization and Public Service Delivery in South Africa. African Trade Policy Centre, Work in Progress, No. 58. Retrieved from https://www.uneca.org/atpc/Work\%20in\%20progress/58.pdf

Hong, Jun Hyun. (2011). Does Decentralization Worsen Regional Disparity? The Case of Korea. Paper presented at the International Conference on Retrospect and Prospect on Public Affairs of the 100th Founding Anniversary of the Republic of China, May 27-29, 2011.

Jin Jing, \& Zou Heng-fu. (2000). Fiscal Decentralization and Economic Growth in China. World Bank Working Paper Series 1452. Retrieved from https://www.World bank.org

Law of the Republic of Indonesia Number 22 of 1948 concerning the Basic Law of the Regional Government along with its Explanation (article 18 paragraph (1) letter c).

Oates, William. (1972). Fiscal Federalism. New York, NY: Harcourt Brace Jovanovich (pp. 162).

Pranab, Bardhan, \& Mookherjee, Dilip. (2005). Decentralization, Corruption and Government Accountability: An Overview. For Handbook of Economic Corruption edited by Susan Rose-Ackerman, Edward Elgar.

Republic of Indonesia. (1974). Law No. 6 of 1974 concerning Basic Provisions for Social Welfare.

Republic of Indonesia. (2004). Law No. 23 of 2014 concerning Regional Government.

Republic of Indonesia. (2007). Government Regulation No. 38 of 2007 concerning Division of Affairs between the Government, Provincial Governments and Municipal District Governments.

Republik of Indonesia Law Number 23 of 2014 concerning Regional Government. 
Slinko, I. (2002). The Impact of Fiscal Desentralization on the Budget Revenue Inequality among Municipalities and Growth of Russian Regions. Centre for Economic and Financial Research, Moskow. Retrieved from https://www/econpaper.repec.org

Stiglitz, Joseph E., Sen, Amartya, \& Fitoussi, Jean-Paul. (2011). Murucori Welfare: Why Gross Domestic Product Is Not the Right Benchmark for Assessing Progress.

Supriyatno, Budi. (2009). Government Management (Plus Twelve Strategic Steps). Publisher of CV. Brilliant Media, Indonesia.

Yogyakarta Central Statistics Agency. (2017).

Zimmerman, Barry J. (1989). A Social Cognitive View of Self-Regulated Academic Learning. Journal of Educational Psychology, 81(3), 329-339. https://doi.org/10.1037/0022-0663.81.3.329

\section{Notes}

Note 1. Central Bureau of Statistics of the Special Region of Yogyakarta Province in 2010.

Note 2. This paragraph was made based on the Law of the Republic of Indonesia Number 22 of 1948 concerning the Basic Law of the Regional Government along with its Explanation (article 18 paragraph (1) letter c).

Note 3. Republik of Indonesia Law Number 23 of 2014 concerning Regional Government.

Note 4. Yogyakarta Central Statistics Agency 2017.

Note 5. Budi Supriyatno. (2009). Government Management (Plus Twelve Strategic Steps). Publisher of CV. Brilliant Media, Indonesia. pp. 234.

Note 6. William Oates. (1972). Fiscal Federalism. New York, NY: Harcourt Brace Jovanovich. pp. 162.

Note 7. G. S. Cheema, \& D. A. Rondinelli. (1983). Decentralization and Development: Policy Implementation in Developing Countries. Beverly Hills; London; New Delhi: Sage Publications. pp. 271.

Note 8. R. Bird, \& F. Vaillancourt. (1998). Fiscal Decentralization in Developing Countries. Cambridge University Press, United Kingdom. pp. 132.

Note 9. Bardhan Pranab, \& Dilip Mookherjee. (2005). Decentralization, Corruption and Government Accountability: An Overview. For Handbook of Economic Corruption edited by Susan Rose-Ackerman, Edward Elgar, pp. 213.

Note 10. A. B. Elhiraika. (2007). Fiscal Decentralization and Public Service Delivery in South Africa. African Trade Policy Centre, Work in Progress, No. 58. Download from http://www.uneca.org/atpc/Work\%20in\%20progress/58.pdf, pp115

Note 11. Jun Hyun Hong. (2011). Does DecenrlizationWorsen Regional Disparity? The Case of Korea. Paper yang dipresentasikanpada International Conference on Retrospect and Prospect on Public Affairs of 100th Founding Anniversary of the Republic of China, 27-29 Mei, 2011. pp. 87-93.

Note 12. Barry J. Zimmerman. (1989). A Social Cognitive View of Self-Regulated Academic Learning. Journal of Educational Psychology 1989, Vol. 81, No. 3, 329-33. Copyright 1989 by the American Psychological Association, Inc. O022-O663/89/J00.75. pp. 56-74

Note 13. Jun Hyun Hong. (2011). Does DecenrlizationWorsen Regional Disparity? The Case of Korea. Paper yang dipresentasikanpada International Conference on Retrospect and Prospect on Public Affairs of 100th Founding Anniversary of the Republic of China, 27-29 Mei, 2011. pp. 87-93.

Note 14. Jun Hyun Hong, (2011). Does Decenrlization Worsen Regional Disparity? The Case of Korea. Paper yang dipresentasikanpada International Conference on Retrospect and Prospect on Public Affairs of 100th Founding Anniversary of the Republic of China, 27-29 Mei, 2011. pp. 87-93.

Note 15. See Article Jin Jing \& Heng-fu Zou (2000). Fiscal Decentralization and Economi Growth in China. World Bank Working Paper Series 1452. Available: http:/www.worldbank.org. pp. 91-94.

Note 16. Robert D Ebel \& SeidarYilmaz. (2002). Concept of Fiscal Desentralization and World Wide Overview. World Bank Institute. Available: http://www.Worldbank.org. pp. 231.

Note 17. A. B. Elhiraika. (2007). Fiscal Decentralization and Public Service Delivery in South Africa. African Trade Policy Centre, Work in Progress, No. 58. Didownloaddari 
https://www.uneca.org/atpc/Work\%20in\%20progress/58.pdf

Note 18. Op. cit. Hong (2011). pp. 87-93.

Note 19. See Aticle Altito (2010), Tasrin (2011), Jin Jin \& Heng-fu, Zou (2000), Slinko, Irina (2002).

Note 20. See Article Jin Jin \& Heng-fu, Zou (2000); Slinko, Irina (2002).

Note 21. Op. cit. Robert D Ebel \& SeidarYilmaz. (2002). pp. 231.

Note 22. Lihatpenelitian Jin \& Heng-fu, Zou (2000), Slinko (2002); Elhiraika (2007); Altito (2010), Tasrin (2011).

Note 23. Op. cit. Hong (2011). pp. 87-93.

Note 24. Ibid. Hong (2011). pp. 87-93.

Note 25. Op. cit. Zimmerman. pp. 74-93.

Note 26. Op. cit. Hong (2011). pp. 87-93.

Note 27. Ibid. Hong (2011). pp. 87-93.

Note 28. Ibid. Hong (2011). pp. 87-93.

Note 29. French President: Nicholas Sarkozy, in February 2008. Establishment of the Commission on Measurement of Economic Performance and Social Progress (CMEPSP).

Note 30. Op. cit. Hong (2011). pp. 87-93.

Note 31. Ibid. Hong (2011). pp. 87-93

Note 32. Ibid. Hong (2011). pp. 87-93

\section{Copyrights}

Copyright for this article is retained by the author(s), with first publication rights granted to the journal.

This is an open-access article distributed under the terms and conditions of the Creative Commons Attribution license (http://creativecommons.org/licenses/by/4.0/). 